\title{
The role of rumen protozoa in the utilization of paspalum (Paspalum dilatatum) hay by cattle
}

\author{
BY B. S. PUNIA AND JANE LEIBHOLZ* \\ Department of Animal Husbandry, University of Sydney, Camden, NSW 2570, Australia \\ AND G. J. FAICHNEY \\ CSIRO, Division of Animal Production, PO Box 239, Blacktown, NSW 2148, Australia
}

(Received 13 January 1986 - Accepted 28 November 1986)

\begin{abstract}
1. Six Friesian heifers $(250 \mathrm{~kg}$ live weight) with permanent cannulas in the rumen and abomasum were allocated at random into two groups of three. One group was treated with Teric GN9 (ICI (Aust.) Ltd) to defaunate the animals during the first two of the four periods of the experiment, after which they were refaunated. The second group was treated with Teric at the end of the first two periods. The dietary treatments were: paspalum (Paspalum dilatatum $)$ hay $(4.1 \mathrm{~kg} / \mathrm{d})$ given alone and the hay supplemented with urea $(20 \mathrm{~g} / \mathrm{kg}$ dry matter $)$.

2. Defaunation was not complete but the approximate volume of protozoa in the rumen of treated animals was less than $6 \%$ of that in the untreated animals.

3. The amount of organic matter (OM) digested in the stomach was lower $(P<0.01)$ in animals with reduced fauna than in those with normal fauna. There were reductions in both the apparent OM digestibility in the total tract (from 0.56 io $0.52, P<0.01$ ) and the proportion of the digestible $O M$ digested in the rumen (from 0.82 to 0.79 , not significant) of animals with reduced fauna. Apparent digestibilities of acid-detergent fibre and neutral-detergent fibre were significantly lower $(P<0 \cdot 01)$ in animals with reduced fauna.

4. The amount of nitrogen disappearing from the stomach was significantly higher $(P<0.01)$ with the urea supplement; effects due to concentrations of protozoa were not significant. The flow of non-ammonia- $\mathrm{N}$ from the abomasum was higher $(P<0.05)$ in animals with reduced fauna than in animals with normal fauna. The flows of bacterial $\mathrm{N}$ from the abomasum and the efficiencies of bacterial $\mathrm{N}$ synthesis were not significantly affected by the treatments. $\mathrm{N}$ retention was higher $(P<0.01)$ in animals receiving the urea supplement but differences due to protozoa were not significant.

5. Protozoal contribution to the microbial $N$ flowing from the rumen of animals with normal fauna was estimated to be 24 and $27 \%$ with and without the urea supplement respectively.

6. Concentrations of rumen-fiuid ammonia-N were reduced $(P<0.05)$ and those of volatile fatty acids were increased $(P<0.01)$ with reduction in protozoal numbers. Molar proportions of propionic acid increased $(P<0.05)$ and of butyric acid decreased $(P<0.01)$ with reduced rumen fauna.

7. Rumen water volume was lower $(P<0.05)$ and the mean retention time of indigestible acid-detergent lignin tended to be higher in animals with reduced fauna. Rumen dry-matter pool and mean retention time of CrEDTA were not significantly different between treatments.
\end{abstract}

The microbial population of the rumen may be divided into the microfauna, consisting mainly of ciliated protozoa, and the microflora, which comprises the bacteria. Although the role of protozoa in fermentation and their nutritional significance to the host has been studied for some time (Hungate, 1966), it is still not well understood (Coleman, 1985).

Abou Akkada \& El-Shazly (1954) and Christiansen et al. (1965) observed better growth in faunated lambs than in protozoa-free lambs. Similar results were obtained in buffalo (Bubalus bubalis) calves by Borhami et al. (1967). There are many reports in which no effect of defaunation was observed on the growth of lambs (Becker \& Everett, 1930; Chalmers et al. 1968; Eadie \& Gill, 1971) and calves (Pounden \& Hibbs, 1950; Hibbs \& Conrad, 1958; Eadie, 1962; Williams \& Dinusson, 1973). By contrast, higher weight gains in cattle and more wool growth in sheep were reported recently in defaunated animals (Bird \& Leng, 1978; Bird et al. 1979; Bird \& Leng, 1984). These variable responses in performance may 
be due to the nature of the experimental diets as well as the physiological state and age of the animals (Veira et al. 1983).

Conrad et al. (1950) and Klopfenstein et al. (1966) found that the elimination of protozoa from the rumen resulted in reduced dry matter (DM) digestion. Similar results were reported by Jouany et al. (1981) and Veira et al. (1983). Ushida et al. (1984) and Veira et al. (1984) also found that the digestion of organic matter $(O M)$ in the rumen was lower in defaunated than faunated sheep.

Lindsay \& Hogan (1972) reported higher microbial OM availability as a result of defaunation of sheep on high-protein diets. Jouany \& Thivend (1983) showed that the protozoal contribution to duodenal microbial nitrogen was small on a diet rich in highly degradable protein. However, protozoal contribution was significant on a diet high in poorly degradable protein (Ushida et al. 1984). Veira et al. (1984) reported that the flow of amino acids from the stomach decreased when sheep, fauna-free from birth, were inoculated with ciliate protozoa.

The proportion of protozoa flowing from the rumen to the omasum of cattle is considerable (Punia et al. 1984a; Punia \& Leibholz, 1984). Nutritional significance to the host of microbial protein and OM synthesized in the rumen would also be dependent on the flow to the intestines for absorption.

In the present experiment the influence of protozoa on nutrient utilization and bacterial protein synthesis was studied in cattle fed on a low-quality roughage alone or supplemented with urea.

\section{MATERIALS AND METHODS}

\section{Animals, management and defaunation procedure}

Six Friesian heifers aged about 2 years (about $250 \mathrm{~kg}$ ), fitted with cannulas in the rumen (100 $\mathrm{mm}$ diameter) and in the abomasum about $50 \mathrm{~mm}$ from the pylorus, were housed in ventilated, individual stalls with water available ad lib. and in continuous lighting. The six animals were randomly allocated to two identical groups of three heifers for defaunation treatment. At $10 \mathrm{~d}$ before each collection period, all animals were fasted for $24 \mathrm{~h}$ after which 70-75 g Teric GN9 (ICI (Aust.) Ltd, Sydney) in $800 \mathrm{ml}$ water (Bird \& Leng, 1978) were infused into the rumen of the three cattle in one group. The amount of feed given to cattle in the untreated group was similar to that eaten by the treated group.

The three treated animals were refaunated by the transfer of rumen digesta from faunated animals, at the end of the first two of the four periods of the experiment, and the other group of three was then treated with Teric in a similar manner to the first group. Animals treated with Teric were housed in a room separate from untreated animals to avoid cross contamination. Care was taken to change overalls and boots, and hands were washed before entering this room during feeding and sampling.

\section{Dietary treatments and feeding}

The basal diet was chopped paspalum (Paspalum dilatatum) hay; its composition (g/kg DM) was: OM 937, N 11.1, neutral-detergent fibre (NDF) 734, acid-detergent fibre (ADF) 391, acid-detergent lignin (ADL) 45.7. The hay was sprayed with a solution supplying ( $\mathrm{g} / \mathrm{kg}$ hay): 60 water, $2 \cdot 0$ sodium, $1 \cdot 2$ sulphur, 0.6 chloride, $0 \cdot 2$ iron and $(\mathrm{mg} / \mathrm{kg}$ hay): 34 zine, 18 manganese, 10 copper, $0 \cdot 07$ cobalt after which it was sprinkled with dicalcium phosphate supplying (g/kg hay): $2 \cdot 3$ calcium and 1.8 phosphorus. Urea $(20 \mathrm{~g} / \mathrm{kg}$ hay) was also dissolved in the mineral solution when required. Animals were given recommended doses of retinol, cholecalciferol and $\alpha$-tocopherol intramuscularly, before the experiment and after two collection periods. The treatments were: normal and reduced 
fauna with and without urea supplementation of the chopped paspalum hay. The diets were offered at $4.1 \mathrm{~kg} \mathrm{DM} / \mathrm{d}$ in eight equal amounts at 3-h intervals. Animals were allowed 3 weeks to adjust to each dietary treatment.

\section{Markers, feeding and sample collections}

CrEDTA and ADL were used to estimate variables relating to digestion. CrEDTA was prepared in solution according to Binnerts et al. (1968). The solution was sprayed onto $50-\mathrm{kg}$ batches of feed in a feed mixer to give a chromium concentration of approximately $200 \mathrm{mg} / \mathrm{kg}$ feed. Labelled feed was stored in hessian sacks until required.

After the adaptation period on their respective diets, animals were given labelled feed for at least $5 \mathrm{~d}$ before digesta, faecal and urine sampling. Rumen and abomasal digesta $(90 \mathrm{ml})$ were collected every $3 \mathrm{~h}$ during the day over a $3 \mathrm{~d}$ period (nine samples). Some of the rumen digesta was strained through cheesecloth. A portion of the strained liquid was diluted $1: 5(\mathrm{v} / \mathrm{v})$ in formol saline $(10 \mathrm{ml}$ formalin plus $90 \mathrm{ml}$ physiological saline $(9 \mathrm{~g}$ sodium chloride/1)) to fix protozoa for counting. Another portion was acidified to $\mathrm{pH}<3$ with $10 \mathrm{M}$-sulphuric acid to stop microbial activity and was used for chemical analysis.

Urine was collected for $4 \mathrm{~d}$ during the sampling period through urethral catheters inserted into the bladder. Sufficient hydrochloric acid ( $5 \mathrm{M}$ ) was added to urine containers to maintain $\mathrm{pH}$ below 2 so as to avoid $\mathrm{N}$ losses. A portion $(10 \mathrm{ml} / \mathrm{l})$ of daily urine output was bulked for each animal; faecal samples were taken from the rectum three times daily during the collections and a standard quantity was bulked for each animal. Bulk samples were stored at $-10^{\circ}$ to await analysis.

After each collection period, labelled feed was withdrawn and animals were given unlabelled feed. Seven rumen digesta samples were collected over the next $31.5 \mathrm{~h}$ to determine marker disappearance rates. On the final day of each period, rumen pool size was measured by manual emptying and weighing of digesta. Samples of DM determination were taken after mixing. All the samples were stored at $-10^{\circ}$.

\section{Sample preparation and analysis}

Protozoa were counted in a standard counting chamber $(0.2 \mathrm{~mm}$ depth) (Mod-Fuchs, Rosenthal, Weber, England). Pipettes with wide tips were used for protozoal samples and samples were well mixed while handling. Protozoa were differentiated into holotrichs (large) and entodiniomorphs. Entodiniomorph protozoa were grouped as large $\left(>1000000 \mu \mathrm{m}^{3}\right)$, medium, and small $\left(<10000 \mu \mathrm{m}^{3}\right)$ on the basis of cell volume. Approximate volume of fauna was calculated assuming the dimensions of 1000000,100000 and $10000 \mu \mathrm{m}^{3}$ for each of the large, medium and small ciliate cells respectively (Warner, 1962), to compare the biomass of protozoa in normal faunated and Teric-treated animals during the collection periods.

Feed, rumen and abomasal digesta and faeces were dried to constant weight at $100^{\circ}$ to determine DM. OM was calculated after igniting the dry samples at $550^{\circ}$ for $5 \mathrm{~h}$ in a muffle furnace. Subsamples of rumen and abomasal digesta and of faeces were dried at $50^{\circ}$ in a forced-draught oven before the analysis of NDF, ADF and ADL (Goering \& Van Soest, 1970). The apparent digestibility coefficients of OM, ADF, NDF and N were calculated by the marker (ADL) ratio technique. $\mathrm{N}$ was estimated by an automated Kjeldahl technique (Kjel-Foss Automatic 16210; A/S N. Foss Electric, Denmark).

Samples of abomasal digesta were strained through cheesecloth and filtered to obtain liquid fractions for $\mathrm{Cr}, \mathrm{DM}, \mathrm{OM}$ and $\mathrm{N}$ analyses. For $\mathrm{Cr}$ analyses, samples $(500 \mathrm{mg})$ of feed, rumen and abomasal digesta and faeces were suspended in $4 \mathrm{ml}$ nitric acid overnight; $4 \mathrm{ml}$ nitric-perchloric acid mixture $(1: 1, \mathrm{v} / \mathrm{v})$ were added next morning and the samples were heated for $3 \mathrm{~h}$ or until clear. Digested sample, liquid fractions and urine were filtered 
and analysed for $\mathrm{Cr}$ by atomic absorption spectrophotometry (Varian Techtron Model AA6DAB; Varian Pty Ltd, Sydney). Flows of digesta were calculated from CrEDTA and ADL concentrations using the double-marker method; all CrEDTA concentrations were corrected for absorption (Faichney, 1975, 1980).

Bacteria were isolated from abomasal samples by differential centrifugation (Mathers \& Miller, 1980). Strained fluid was centrifuged at $1750 \mathrm{~g}$ for $10 \mathrm{~min}$ to remove protozoa and feed particles. The supernatant fluid was then centrifuged at $27750 \mathrm{~g}$ for $20 \mathrm{~min}$ and the pellet thus obtained was washed with Brij saline ( $2 \mathrm{ml}$ Brij in 4 litres saline) and centrifuged twice to obtain bacterial samples.

Bacterial and digesta samples were freeze-dried and analysed for 2,6-diaminopimelic acid (DAPA) by ion-exchange chromatography using an automatic amino acid analyser (TSM AutoAnalyzer; Technicon Instrument Corporation, Tarry Town, New York) following hydrolysis in $6 \mathrm{M}-\mathrm{HCl}\left(110^{\circ}, 22 \mathrm{~h}\right)$ and oxidation overnight in performic acid ( $1 \mathrm{ml}$ hydrogen peroxide $(300 \mathrm{ml} / \mathrm{l})+9 \mathrm{ml}$ formic acid $(880 \mathrm{ml} / 1)$ ) (Moore, 1963). Norleucine was used as internal standard. The DAPA: $\mathrm{N}$ was calculated for each sample of bacteria and digesta. The proportion of bacterial $\mathrm{N}$ in the digesta was calculated as the DAPA: $\mathrm{N}$ of digesta divided by the DAPA: $N$ of bacteria. The DAPA concentration in bacteria was 30 (SE $0.3) \mathrm{mg} / \mathrm{g} \mathrm{N}$. $\mathrm{N}$ in the hydrolysates was determined by a micro-Kjeldahl method.

An estimate of the protozoal contribution to the microbial $\mathrm{N}$ flow was made using differential (holotrichs, and large, medium and small entodiniomorphs) protozoal counts in the rumen fluid (Table 1) and the relative flow of protozoa to the omasum $(0.64$ for the holotrichs and $0.57,0.58$ and 0.36 respectively for the large, medium and small entodiniomorphs, taken from Punia et al. 1984a), assuming that protozoa were suspended in the daily flow of water to the omasum (Table 5, p. 402). The holotrichs and large entodiniomorphs were assumed to have $17.8 \mathrm{~g} \mathrm{DM} / 10^{8}$ cells (Leng et al. 1981) and the medium and small entodinia 2.0 and $0.2 \mathrm{~g} \mathrm{DM} / 10^{8}$ cells respectively based on their size (Broad \& Dawson, 1975). N content in this protozoal DM was taken as $35.3 \mathrm{mg} / \mathrm{g}$ (Punia \& Leibholz, 1984). This is within the range of values given in Hungate (1966) and more recently by Bauchart et al. (1986). Approximate DM of protozoa in the rumen fluid was also calculated and compared with the approximate protozoal cell volume (Table 1).

Total volatile fatty acids (VFA) and their molar proportions in rumen fluid were analysed by gas-liquid chromatography using 3-methyl- $n$-valeric acid as an internal standard. Ammonia- $\mathrm{N}$ in the rumen and abomasal fluids was determined by the method of Chaney \& Marbach (1962).

Mean retention time of CrEDTA in the rumen was calculated as the reciprocal of the rate constant for its disappearance and was corrected for the absorption of $\mathrm{Cr}$ from the rumen (Faichney, 1986). Lignin mean retention time was calculated from indigestible ADL content in and flow from the rumen (Faichney, 1980).

\section{Statistical analysis}

Experimental values were examined statistically by the analysis of variance for an incomplete Latin-square design. Effects of fauna $(F)$, urea $(U)$ and their interaction $(F \times U)$ were tested against the residual mean square $(12 \mathrm{df})$. The least significant difference $(P<0.05)$ was used to compare treatment means (Steel \& Torrie, 1980).

\section{RESULTS}

Protozoal numbers and the approximate volume and DM of fauna in the rumen fluid are presented in Table 1. Treatment with Teric removed medium and large protozoa but small Entodinium spp. reappeared in the rumen of these animals. Thus the volume of protozoa 
Table 1. Protozoal counts $\left(\times 10^{-4} / \mathrm{ml}\right)$ and their approximate volume and dry matter $(D M)$ in the rumen fluid of experimental animals during the collection periods

(Each value is the mean of six replicates)

\begin{tabular}{|c|c|c|c|c|c|c|c|c|}
\hline \multirow{2}{*}{$\begin{array}{l}\text { Group } \ldots \\
\text { Urea supplement } \\
(\mathrm{g} / \mathrm{kg} \mathrm{DM}) \quad \ldots\end{array}$} & \multicolumn{2}{|c|}{ Normal fauna } & \multicolumn{2}{|c|}{ Reduced fauna } & \multirow[b]{2}{*}{$\begin{array}{c}\text { SEM } \\
(12 \mathrm{df})\end{array}$} & \multicolumn{3}{|c|}{$\begin{array}{c}\text { Statistical } \\
\text { significance of }\end{array}$} \\
\hline & 20 & 0 & 20 & 0 & & $\begin{array}{l}\text { Fauna } \\
\text { (F) }\end{array}$ & $\begin{array}{c}\text { Urea } \\
(\mathrm{U})\end{array}$ & $\mathrm{F} \times \mathrm{U}$ \\
\hline Holotrichs & 0.8 & $1 \cdot 3$ & $0 \cdot 2$ & $0 \cdot 1$ & $0 \cdot 10$ & ** & NS & $*$ \\
\hline $\begin{array}{l}\text { Entodiniomorphs: } \\
\text { Large }\left(>1000000 \mu \mathrm{m}^{3}\right) \\
\text { Medium } \\
\text { Small }\left(<10000 \mu \mathrm{m}^{3}\right)\end{array}$ & $\begin{array}{l}2 \cdot 7 \\
3 \cdot 8 \\
9 \cdot 0\end{array}$ & $\begin{array}{r}3 \cdot 5 \\
4 \cdot 5 \\
12 \cdot 4\end{array}$ & $\begin{array}{l}0 \cdot 0 \\
0 \cdot 7 \\
8 \cdot 1\end{array}$ & $\begin{array}{r}0 \cdot 0 \\
0 \cdot 9 \\
16 \cdot 3\end{array}$ & $\begin{array}{l}0 \cdot 13 \\
0 \cdot 30 \\
1 \cdot 19\end{array}$ & $\begin{array}{l}* * \\
* * \\
\text { NS }\end{array}$ & $\begin{array}{c}* \\
\text { NS } \\
* *\end{array}$ & $\begin{array}{l}\text { NS } \\
\text { NS } \\
\text { NS }\end{array}$ \\
\hline Total ciliates & $16 \cdot 3$ & $21 \cdot 7$ & $9 \cdot 0$ & $17 \cdot 3$ & $1 \cdot 25$ & $* *$ & $* *$ & NS \\
\hline $\begin{array}{l}\text { Approximate volume } \\
\text { of total ciliates } \\
\left(\mu \mathrm{m}^{3}\left(\times 10^{8}\right) / \mathrm{ml}\right)\end{array}$ & $40 \cdot 4$ & $53 \cdot 2$ & $1 \cdot 5$ & $3 \cdot 0$ & 1.46 & $* *$ & $* *$ & $*$ \\
\hline $\begin{array}{l}\text { Approximate DM of total } \\
\text { ciliates }(\mathrm{mg} / \mathrm{ml})\end{array}$ & $7 \cdot 2$ & $9 \cdot 7$ & 0.7 & $0 \cdot 7$ & 0.28 & $* *$ & $* *$ & $*$ \\
\hline
\end{tabular}

NS, not significant. $\quad * P<0.05, * * P<0.01$

Table 2. Intake of dry matter $(D M)$ and digestion of organic matter $(O M)$ in heifers with normal and reduced fauna, eating paspalum (Paspalum dilatatum) hay with or without $20 \mathrm{~g}$ urea/kg DM

(Each value is the mean of six replicates)

\begin{tabular}{|c|c|c|c|c|c|c|c|}
\hline \multirow{3}{*}{$\begin{array}{l}\text { Group } \ldots \\
\text { Urea supplement } \\
(\mathrm{g} / \mathrm{kg} \mathrm{DM}) \quad \ldots\end{array}$} & \multirow{2}{*}{\multicolumn{2}{|c|}{ Normal fauna }} & \multirow{2}{*}{\multicolumn{2}{|c|}{ Reduced fauna }} & \multirow{3}{*}{$\begin{array}{c}\text { SEM } \\
(12 \mathrm{df})\end{array}$} & \multicolumn{2}{|c|}{$\begin{array}{c}\text { Statistical } \\
\text { significance of }\end{array}$} \\
\hline & & & & & & \multirow{2}{*}{$\begin{array}{l}\text { Fauna } \\
\qquad(\mathrm{F})\end{array}$} & \multirow{2}{*}{$\begin{array}{l}\text { Urea } \\
\text { (U) }\end{array}$} \\
\hline & 20 & 0 & 20 & 0 & & & \\
\hline DM intake $(\mathrm{g} / \mathrm{d})$ & 4185 & 4132 & 4115 & 4057 & $\overline{25} \cdot 8$ & NS & NS \\
\hline OM intake $(g / d)$ & 3923 & 3877 & 3860 & 3798 & $25 \cdot 0$ & NS & NS \\
\hline $\begin{array}{l}\text { OM apparently digested in: } \\
\text { Stomach }(\mathrm{g} / \mathrm{d}) \\
\text { Total tract }(\mathrm{g} / \mathrm{d})\end{array}$ & $\begin{array}{l}1847 \\
2249\end{array}$ & $\begin{array}{l}1734 \\
2115\end{array}$ & $\begin{array}{l}1591 \\
2026\end{array}$ & $\begin{array}{l}1581 \\
1979\end{array}$ & $\begin{array}{l}19 \cdot 2 \\
35 \cdot 4\end{array}$ & ** & $\stackrel{*}{N S}$ \\
\hline $\begin{array}{l}\text { Apparent digestibility } \\
\text { coefficient of OM }\end{array}$ & 0.57 & 0.55 & 0.52 & 0.52 & 0.009 & $* *$ & NS \\
\hline $\begin{array}{l}\text { Fraction of digestible } \\
\text { OM apparently digested in stomach }\end{array}$ & 0.82 & 0.82 & $0 \cdot 78$ & $0 \cdot 80$ & 0.011 & NS & NS \\
\hline
\end{tabular}

$\mathrm{F} \times \mathrm{U}$ interactions were not statistically significant.

NS, not significant.

$* P<0.05, * * P<0.01$.

in the rumen of treated animals was less than $6 \%$ (and less than $8 \%$ of the DM of fauna) of that present in the rumen of untreated animals.

The DM intake of the heifers was maintained at $4 \cdot 1 \mathrm{~kg} / \mathrm{d}$, which gave OM intakes of $3.80-3.92 \mathrm{~kg} / \mathrm{d}$ for the four treatments (Table 2). The amount of OM digested in the stomach was lower $(P<0.01)$ in animals with reduced fauna than in those with normal 
Table 3. Digestion of acid-detergent fibre $(A D F)$ and neutral-detergent fibre $(N D F)$ in heifers with normal and reduced fauna, eating paspalum (Paspalum dilatatum) hay with or without $20 \mathrm{~g}$ urea/kg dry matter $(D M)$

(Each value is the mean of six replicates)

\begin{tabular}{|c|c|c|c|c|c|c|c|c|}
\hline \multirow{3}{*}{$\begin{array}{l}\text { Group } \ldots \\
\text { Urea supplement } \\
(\mathrm{g} / \mathrm{kg} \mathrm{DM}) \quad \ldots\end{array}$} & \multirow{2}{*}{\multicolumn{2}{|c|}{ Normal fauna }} & \multirow{2}{*}{\multicolumn{2}{|c|}{ Reduced fauna }} & \multirow{3}{*}{$\begin{array}{c}\text { SEM } \\
(12 \mathrm{df})\end{array}$} & \multicolumn{3}{|c|}{$\begin{array}{c}\text { Statistical } \\
\text { significance of }\end{array}$} \\
\hline & & & & & & \multirow{2}{*}{$\begin{array}{c}\text { Fauna } \\
(\mathrm{F})\end{array}$} & \multirow{2}{*}{$\begin{array}{l}\text { Urea } \\
\text { (U) }\end{array}$} & \multirow[b]{2}{*}{$\mathrm{F} \times \mathrm{U}$} \\
\hline & 20 & 0 & 20 & 0 & & & & \\
\hline ADF intake $(\mathrm{g} / \mathrm{d})$ & 1627 & 1628 & 1595 & 1606 & $9 \cdot 2$ & NS & NS & NS \\
\hline $\begin{array}{l}\text { ADF apparently diges } \\
\text { Stomach }(\mathrm{g} / \mathrm{d}) \\
\text { Total tract }(\mathrm{g} / \mathrm{d})\end{array}$ & $\begin{array}{l}893 \\
908\end{array}$ & $\begin{array}{l}881 \\
871\end{array}$ & $\begin{array}{l}787 \\
809\end{array}$ & $\begin{array}{l}786 \\
822\end{array}$ & $\begin{array}{r}8 \cdot 3 \\
15 \cdot 6\end{array}$ & $\begin{array}{l}* * \\
* *\end{array}$ & $\begin{array}{l}\text { NS } \\
\text { NS }\end{array}$ & $\stackrel{*}{*}$ \\
\hline $\begin{array}{l}\text { Apparent digestibility } \\
\text { coefficient of ADF }\end{array}$ & 0.55 & 0.53 & 0.50 & 0.51 & 0.009 & $* *$ & NS & NS \\
\hline NDF intake $(\mathrm{g} / \mathrm{d})$ & 3063 & 3058 & 3008 & 2977 & $19 \cdot 1$ & NS & NS & NS \\
\hline $\begin{array}{l}\text { NDF apparently diges } \\
\text { Stomach }(\mathrm{g} / \mathrm{d}) \\
\text { Total tract }(\mathrm{g} / \mathrm{d})\end{array}$ & $\begin{array}{l}1757 \\
1865\end{array}$ & $\begin{array}{l}1695 \\
1786\end{array}$ & $\begin{array}{l}1515 \\
1686\end{array}$ & $\begin{array}{l}1492 \\
1643\end{array}$ & $\begin{array}{l}24 \cdot 0 \\
33 \cdot 5\end{array}$ & $\underset{* *}{\text { NS }}$ & $\begin{array}{l}\text { NS } \\
\text { NS }\end{array}$ & $\stackrel{*}{N S}$ \\
\hline $\begin{array}{l}\text { Apparent digestibility } \\
\text { coefficient of NDF }\end{array}$ & 0.61 & $0 \cdot 59$ & 0.56 & 0.56 & 0.009 & $* *$ & NS & NS \\
\hline
\end{tabular}

NS, not significant. $\quad * P<0.05, * * P<0.01$.

fauna. Apparent digestibility of $O M$ in the total tract was also lower $(P<0.01)$ for the heifers with reduced fauna. There was a tendency for a lower proportion $(0.79 v .0 .82)$ of the OM digestion to occur in the stomach of animals with reduced fauna compared with those with normal fauna.

The heifers with reduced fauna digested less $(P<0 \cdot 01)$ ADF and NDF in the rumen and in the total gastrointestinal tract than did those with normal fauna (Table 3).

Urea supplementation tended to improve the digestibilities of feed components slightly in animals with normal fauna but had no significant effect overall. The supplement of urea increased $\mathrm{N}$ intake by $76 \%$ (Table 4). The amount of $\mathrm{N}$ disappearing from the stomach was higher $(P<0.01)$ with the urea supplement than with paspalum alone. The flow of non- $\mathrm{NH}_{3}-\mathrm{N}(\mathrm{NAN})$ from the abomasum was higher $(P<0.05)$ in animals with reduced fauna than in those with normal fauna. The differences in the amounts of NAN digested in the intestines, however, were not significant.

Total bacterial $\mathrm{N}$ flows were similar on all the treatments but the bacterial proportion of the NAN flowing from the abomasum was lower $(P<0.05)$ in animals with reduced fauna. Differences due to urea supplementation were not significant. Efficiency of bacterial $\mathrm{N}$ synthesis showed no significant difference between treatments.

Protozoal contribution to microbial $\mathrm{N}$ flow to the omasum was estimated to be respectively 24 and $27 \%$, in animals with normal fauna with and without urea supplement. Protozoa constituted $2 \%$ of the microbial $\mathrm{N}$ flow in animals with reduced fauna with and without urea supplement.

Faecal and urinary $\mathrm{N}$ excretions were significantly different between treatments (Table 4). $\mathrm{N}$ retention was higher $(P<0 \cdot 01)$ with the urea supplement, but the differences between the groups with normal and reduced fauna were not significant. Concentrations of rumen fluid $\mathrm{NH}_{3}-\mathrm{N}$ were lower $(P<0.05)$ in animals with reduced fauna than in those with normal 
Table 4. Intake and digestion of nitrogen, abomasal flows of bacterial and protozoal $N$ and efficiencies of bacterial and total microbial $N$ synthesis in heifers with normal and reduced fauna, eating paspalum (Paspalum dilatatum) hay with or without $20 \mathrm{~g}$ urea/kg dry matter $(D M)$

(Each value is the mean of six replicates)

\begin{tabular}{|c|c|c|c|c|c|c|c|}
\hline \multirow{3}{*}{$\begin{array}{l}\text { Group } \\
\text { Urea supplement } \\
(\mathrm{g} / \mathrm{kg} \mathrm{DM}) \quad \ldots\end{array}$} & \multirow{2}{*}{\multicolumn{2}{|c|}{ Normal fauna }} & \multirow{2}{*}{\multicolumn{2}{|c|}{ Reduced fauna }} & \multirow{3}{*}{$\begin{array}{c}\text { SEM } \\
(12 \mathrm{df})\end{array}$} & \multicolumn{2}{|c|}{$\begin{array}{c}\text { Statistical } \\
\text { significance of }\end{array}$} \\
\hline & & & & & & \multirow{2}{*}{$\begin{array}{c}\text { Fauna } \\
(\mathrm{F})\end{array}$} & \multirow{2}{*}{$\begin{array}{l}\text { Urea } \\
\text { (U) }\end{array}$} \\
\hline & 20 & 0 & 20 & 0 & & & \\
\hline Total $N$ intake $(g / d)$ & $81 \cdot 5$ & $44 \cdot 4$ & $79 \cdot 3$ & $46 \cdot 2$ & - & - & - \\
\hline $\mathrm{N}$ intake from urea $(\mathrm{g} / \mathrm{d})$ & $35 \cdot 5$ & 0.0 & $34 \cdot 0$ & $0 \cdot 0$ & - & - & - \\
\hline $\begin{array}{l}\text { Apparent digestibility } \\
\text { coefficient of } \mathrm{N}\end{array}$ & 0.67 & $0 \cdot 40$ & 0.63 & 0.41 & 0.007 & NS & $* *$ \\
\hline \multicolumn{8}{|l|}{$N$ excretion $(\mathrm{g} / \mathrm{d})$ : } \\
\hline Urinary & $44 \cdot 2$ & $15 \cdot 6$ & $39 \cdot 4$ & $12 \cdot 3$ & 0.95 & $* *$ & $* *$ \\
\hline Faecal & $26 \cdot 8$ & $26 \cdot 6$ & $29 \cdot 6$ & $27 \cdot 3$ & 0.33 & $* *$ & $*$ \\
\hline$N$ retention $(\mathrm{g} / \mathrm{d})$ & $10 \cdot 5$ & $2 \cdot 2$ & $10 \cdot 3$ & $6 \cdot 6$ & 0.97 & NS & ** \\
\hline $\begin{array}{l}N \text { apparently digested } \\
\text { in stomach }(\mathrm{g} / \mathrm{d})\end{array}$ & $26 \cdot 8$ & $-7 \cdot 8$ & $18 \cdot 3$ & $-7 \cdot 1$ & 1.63 & NS & $* *$ \\
\hline $\begin{array}{l}\text { Non-ammonia-N (NAN) } \\
\text { flow from abomasum }(\mathrm{g} / \mathrm{d})\end{array}$ & $50 \cdot 6$ & $51 \cdot 0$ & $57 \cdot 0$ & $52 \cdot 4$ & $1 \cdot 36$ & $*$ & NS \\
\hline $\begin{array}{l}\text { NAN apparently digested } \\
\text { in intestines }(\mathrm{g} / \mathrm{d})\end{array}$ & $23 \cdot 8$ & $24 \cdot 4$ & $27 \cdot 3$ & $25 \cdot 0$ & $1 \cdot 53$ & NS & NS \\
\hline $\begin{array}{l}\text { Proportion of abomasal } \\
\text { NAN flow apparently } \\
\text { digested }\end{array}$ & 0.47 & 0.48 & $0 \cdot 47$ & 0.48 & 0.019 & NS & NS \\
\hline \multicolumn{8}{|l|}{ Bacterial $\mathrm{N}$ : } \\
\hline Flow from abomasum $(\mathrm{g} / \mathrm{d})$ & $32 \cdot 4$ & $32 \cdot 0$ & $33 \cdot 0$ & $28 \cdot 5$ & $1 \cdot 26$ & NS & NS \\
\hline $\begin{array}{l}\text { Proportion in abomasal } \\
\text { NAN }\end{array}$ & 0.64 & 0.63 & 0.58 & 0.54 & $0 \cdot 019$ & $*$ & NS \\
\hline $\begin{array}{l}\mathrm{g} / \mathrm{kg} \text { OM apparently } \\
\text { digested in stomach }\end{array}$ & $17 \cdot 9$ & $18 \cdot 6$ & $21 \cdot 2$ & $18 \cdot 3$ & $0 \cdot 80$ & NS & NS \\
\hline \multicolumn{8}{|l|}{ Calculated protozoal $\mathrm{N}$ : } \\
\hline Flow to omasum $(\mathrm{g} / \mathrm{d})$ & $10 \cdot 2$ & $11 \cdot 7$ & $0 \cdot 7$ & $0 \cdot 7$ & 0.44 & $* *$ & NS \\
\hline $\begin{array}{l}\text { Proportion in total } \\
\text { microbial N }\end{array}$ & $0 \cdot 24$ & 0.27 & $0 \cdot 02$ & 0.02 & 0.011 & $* *$ & NS \\
\hline \multicolumn{8}{|l|}{ Total microbial $\mathrm{N}$ : } \\
\hline Abomasal flow $(\mathrm{g} / \mathrm{d})$ & $42 \cdot 9$ & $43 \cdot 7$ & $33 \cdot 7$ & $29 \cdot 3$ & $1 \cdot 32$ & $* *$ & NS \\
\hline $\begin{array}{l}\mathrm{g} / \mathrm{kg} \text { OM apparently } \\
\text { digested in stomach }\end{array}$ & $22 \cdot 2$ & $24 \cdot 3$ & $21 \cdot 3$ & 18.8 & 0.78 & $* *$ & NS \\
\hline
\end{tabular}

$\mathrm{F} \times \mathrm{U}$ interactions were not statistically significant.

NS, not significant.

$* P<0.05$,** $P<0.01$.

fauna (Table 5). $\mathrm{NH}_{3}-\mathrm{N}$ values were significantly higher $(P<0 \cdot 01)$, both in normal- and reduced-fauna groups, with the urea supplement.

Concentrations of total VFA and the molar proportion of propionate were higher ( $P<0.01$ and $P<0.05$ respectively) in animals with reduced fauna than in those with normal fauna (Table 5). Animals with reduced fauna exhibited lower $(P<0.01)$ molar proportions of butyrate than those with normal fauna. 
Table 5. Concentrations of ammonia nitrogen and volatile fatty acids (VFA) in rumen fluid, molar proportions of VFA, rumen pool size and mean retention time of markers in the stomach of heifers with normal and reduced fauna, eating paspalum (Paspalum dilatatum) hay with or without $20 \mathrm{~g}$ urea/kg dry matter $(D M)$

(Each value is the mean of six replicates)

\begin{tabular}{|c|c|c|c|c|c|c|c|}
\hline \multirow{3}{*}{$\begin{array}{l}\text { Group } \ldots \\
\text { Urea supplement } \\
(\mathrm{g} / \mathrm{kg} \text { DM }) \quad \ldots\end{array}$} & \multirow{2}{*}{\multicolumn{2}{|c|}{ Normal fauna }} & \multirow{2}{*}{\multicolumn{2}{|c|}{ Reduced fauna }} & \multirow{3}{*}{$\begin{array}{l}\text { SEM } \\
(12 \mathrm{~d} f)\end{array}$} & \multicolumn{2}{|c|}{$\begin{array}{l}\text { Statistical } \\
\text { significance of }\end{array}$} \\
\hline & & & & & & \multirow{2}{*}{$\begin{array}{l}\text { Fauna } \\
\text { (F) }\end{array}$} & \multirow{2}{*}{$\begin{array}{c}\text { Urea } \\
(\mathbf{U})\end{array}$} \\
\hline & 20 & 0 & 20 & 0 & & & \\
\hline Rumen $\mathrm{NH}_{3}(\mathrm{mg} / \mathrm{l})$ & 190 & 23 & 171 & 9 & $5 \cdot 3$ & $*$ & $* *$ \\
\hline Total VFA (mmol/l) & 61 & 60 & 66 & 75 & $2 \cdot 4$ & ** & NS \\
\hline Acetic $(\mathrm{mmol} / \mathrm{mol})$ & 756 & 759 & 770 & 775 & 3.6 & $*$ & NS \\
\hline Propionic (mmol/mol) & 146 & 141 & 164 & 152 & $4 \cdot 7$ & $*$ & NS \\
\hline Butyric $\dagger(\mathrm{mmol} / \mathrm{mol})$ & 88 & 91 & 57 & 65 & $2 \cdot 4$ & $* *$ & NS \\
\hline Valerict $(\mathrm{mmol} / \mathrm{mol})$ & 10 & 9 & 9 & 8 & 0.4 & $*$ & NS \\
\hline \multicolumn{8}{|l|}{ Rumen pool size $(\mathrm{kg})$ : } \\
\hline Water & $40 \cdot 0$ & $39 \cdot 8$ & $35 \cdot 6$ & $37 \cdot 1$ & $1 \cdot 18$ & $*$ & NS \\
\hline DM & $5 \cdot 7$ & $5 \cdot 6$ & $5 \cdot 6$ & $5 \cdot 2$ & 0.17 & NS & NS \\
\hline \multicolumn{8}{|l|}{ Mean retention time (h) } \\
\hline CrEDTA & $13 \cdot 9$ & $16 \cdot 3$ & $16 \cdot 4$ & $14 \cdot 9$ & 0.77 & NS & NS \\
\hline $\begin{array}{l}\text { Indigestible acid- } \\
\text { detergent lignin }\end{array}$ & $64 \cdot 5$ & $57 \cdot 4$ & $72 \cdot 7$ & $60 \cdot 2$ & $2 \cdot 25$ & NS & $* *$ \\
\hline $\begin{array}{l}\text { Water flow from } \\
\text { abomasum }(1 / d)\end{array}$ & $48 \cdot 2$ & $48 \cdot 3$ & $48 \cdot 6$ & $47 \cdot 9$ & $1 \cdot 60$ & NS & NS \\
\hline $\begin{array}{l}\text { Water flow to } \\
\text { omasum }(1 / d)\end{array}$ & $69 \cdot 9$ & $59 \cdot 9$ & $54 \cdot 2$ & $61 \cdot 1$ & $4 \cdot 36$ & NS & NS \\
\hline $\begin{array}{l}\text { Apparent water loss } \\
\text { in omasum-abomasum }(1 / d)\end{array}$ & $21 \cdot 7$ & $11 \cdot 6$ & $5 \cdot 6$ & $13 \cdot 2$ & $3 \cdot 18$ & NS & NS \\
\hline
\end{tabular}

$\mathrm{F} \times \mathrm{U}$ interactions were not significant.

NS, not significant.

* $P<0.05, * * P<0.01$.

$\uparrow$ Sum of $\mathrm{n}$ - and iso-isomers.

The presence of normal fauna was associated with greater rumen water volume $(P<0.05)$ and a tendency towards lower mean retention time of indigestible ADL. The amount of DM present in the rumen, and CrEDTA mean retention time, were not affected by the reduction in protozoal numbers or urea supplementation.

\section{DISCUSSION}

\section{Defaunation of the rumen}

Defaunation of the rumen appeared to be complete for $2-4 \mathrm{~d}$ following dosing of the cattle (with Teric GN9) but low numbers of protozoa, mainly small Entodinium spp., appeared over the next $10 \mathrm{~d}$. These protozoa represented a small volume (less than $6 \%$ ) of fauna compared with that in the untreated group during the collection periods. Similarly, the calculated DM of reduced fauna was also small (about $8 \%$ of normal fauna). Animals in the untreated group harboured a normal fauna consisting of the holotrichs and large, medium and small entodiniomorphs.

The dose of Teric was not increased to eliminate protozoa completely because, in 
Table 6. Effects of protozoa on digestion and nitrogen flow to the duodenum

\begin{tabular}{|c|c|c|c|c|}
\hline \multirow[b]{2}{*}{ Main diet } & \multirow[b]{2}{*}{ Constituent } & \multicolumn{2}{|c|}{$\begin{array}{l}\text { Apparent digestibility } \\
\text { coefficient of feed } \\
\text { constituents }\end{array}$} & \multirow[b]{2}{*}{ Reference } \\
\hline & & Faunated & Defaunated & \\
\hline $\begin{array}{l}\text { Lucerne (Medicago } \\
\text { sativa) hay }\end{array}$ & $\mathrm{DM}$ & 0.66 & 0.63 & Conrad et al. (1950) \\
\hline Pasture grass & & $0 \cdot 72$ & 0.72 & Conrad et al. (1950) \\
\hline Concentrate & & $0 \cdot 78$ & $0 \cdot 74$ & Klopfenstein et al. (1966) \\
\hline Concentrate & & $0 \cdot 74$ & 0.64 & Klopfenstein et al. (1966) \\
\hline Lucerne hay & OM & 0.65 & 0.62 & Lindsay \& Hogan (1972) \\
\hline $\begin{array}{l}\text { Red clover } \\
\text { (Trifolium pratense) }\end{array}$ & & $0 \cdot 76$ & $0 \cdot 75$ & Lindsay \& Hogan (1972) \\
\hline Meadow hay & ADF & 0.71 & 0.69 & Jouany \& Senaud (1979) \\
\hline Meadow hay + barley & & 0.60 & 0.56 & Jouany \& Senaud (1979) \\
\hline \multirow[t]{3}{*}{ Maize + maize silage } & OM & 0.53 & 0.43 & Veira et al. $(1983)^{*}$ \\
\hline & ADF & 0.42 & 0.34 & Veira et al. $(1983)^{*}$ \\
\hline & Starch & $0 \cdot 89$ & 0.84 & Veira et al. (1983)* \\
\hline Grass hay + concentrate & $\mathrm{OM}$ & 0.54 & 0.47 & Veira et al. (1984)* \\
\hline Lucerne hay + barley & OM & 0.61 & 0.59 & Ushida et al. (1984) \\
\hline Concentrate & DM & $0 \cdot 84$ & 0.83 & Whitelaw et al. (1984) \\
\hline \multicolumn{5}{|c|}{$\mathrm{N}$ flow to the duodenum ( $\mathrm{g}$ bacterial $\mathrm{N} / \mathrm{d}$ ) (sheep) } \\
\hline Lucerne hay & & $12 \cdot 0$ & 14.0 & Lindsay \& Hogan (1972) \\
\hline Red clover & & $18 \cdot 0$ & $19 \cdot 3$ & Lindsay \& Hogan (1972) \\
\hline $\begin{array}{l}\text { Alkali-treated wheat } \\
\text { straw + sugar beet }\end{array}$ & & $16 \cdot 3$ & $16 \cdot 0$ & Jouany \& Thivend (1983) \\
\hline Pelleted (lucerne & & $12 \cdot 1$ & $17 \cdot 7$ & Ushida et al. (1984) \\
\hline \multicolumn{5}{|c|}{ Total amino acids flow (g/kg DM intake) } \\
\hline Maize + maize silage & & 101 & 126 & Veira et al. (1983) \\
\hline Grass hay + concentrate & & 89 & 124 & Veira et al. (1984) \\
\hline
\end{tabular}

DM, dry matter; OM, organic matter; ADF, acid-detergent fibre.

* Digestibility in rumen.

preliminary trials, some animals showed toxic symptoms at higher doses. Burggraaf \& Leng (1980) also reported that the dose required for complete defaunation had adverse effects on some animals. Difficulties in defaunation of ruminants have also been reported by Lovelock et al. (1982) and Veira et al. (1983). In the absence of an ideal defaunating agent, the present experiment was conducted to investigate the effects of substantially reducing the protozoal population.

\section{Feed utilization}

The results of the present study showed that the digestibility of OM in the rumen of heifers with reduced fauna was lower than in heifers with a normal fauna. The major cause of this lower digestibility was reduced digestion of fibre in the rumen. Studies with defaunated sheep by Jouany \& Senaud (1979) and Veira et al. (1983) showed that protozoa aided digestion in the rumen. Veira et al. (1983) found that the digestion of OM and starch was significantly improved by the presence of protozoa, while the improvement in the digestion of ADF was not significant. However, the ADF content of their diets was only $74 \mathrm{~g} / \mathrm{kg}$ compared with $391 \mathrm{~g} / \mathrm{kg}$ in the present experiment. Jouany \& Senaud (1982) showed that the presence of protozoa in the rumen increased the bacterial cellulolytic activity for the diet containing $355 \mathrm{~g} \mathrm{ADF} / \mathrm{kg}$ but not for that containing $204 \mathrm{~g} \mathrm{ADF} / \mathrm{kg}$. 
The effects of protozoa on the digestion of feed constituents in the gastrointestinal tract and $\mathbf{N}$ supply to the duodenum as reported in the literature are summarized in Table 6. It is apparent from this table and the present experiment that protozoa improve the digestibility on most diets.

\section{$N$ metabolism and protein synthesis in the rumen}

Veira et al. (1983, 1984; Table 6) reported higher NAN and amino acid flows from the duodenum in defaunated sheep than in sheep with normal fauna. In the present experiment also, the flow of NAN from the abomasum was higher in animals with reduced fauna, but the bacterial proportion of the NAN was lower than that in animals with normal fauna so that flows of bacterial $\mathrm{N}$ from the abomasum in the two groups were similar. However, the flow of microbial $\mathrm{N}$ from the abomasum was substantially lower in the animals with reduced fauna so that the higher NAN flows from the abomasum of these animals indicate that the degradation of dietary $\mathrm{N}$ in the rumen was reduced. The faecal excretion of $\mathrm{N}$ was higher in animals with reduced fauna so that the amount of NAN apparently digested in the intestines was not different between the treatments.

The results suggest that neither the reduction of protozoal population nor the supplementation with urea affected the efficiencies of bacterial protein synthesis. Ushida et al. (1984) reported higher efficiencies of bacterial protein synthesis and greater bacterial $\mathrm{N}$ flows to the duodenum in defaunated sheep. They concluded that defaunation increased the amount of dietary protein that escaped from the rumen undegraded and allowed the utilization of more recycled $\mathrm{N}$ to maintain bacterial protein flow to the duodenum, especially when the diet was rich in proteins of low solubility and supported high numbers of protozoa in the rumen. The lack of an effect of protozoa on bacterial $\mathbf{N}$ flows in the present experiment may be due to the difference in the type of diet used since the hay contained only $11 \cdot 1 \mathrm{gN} / \mathrm{kg}$ and protozoal numbers were low compared with those in the experiment of Ushida et al. (1984).

Faunation of the rumen has been reported to decrease the bacterial population in the rumen fluid (Eadie \& Hobson, 1962; Kurihara et al. 1968, 1987; Eadie \& Gill, 1971). However, Jouany et al. (1981) did not find an increase in total bacterial numbers in defaunated sheep and Jounay \& Thivend (1983) reported similar flows of bacterial $N$ to the duodenum in faunated and defaunated animals (see Table 6).

The flow of protozoal $\mathbf{N}$ to the omasum was used to calculate the contribution of protozoa in microbial $\mathrm{N}$ flow from the abomasum (Table 4); assuming that all the protozoa flowing to the omasum reached the abomasum. There is no direct evidence in the literature that protozoa are destroyed in the omasum (see Smith, 1984).

The calculated protozoal contribution reported in the present paper must be considered as a minimum value because protozoa associated with the solids were not accounted for. This underestimation is partly compensated for by the assumption that the protozoal counts made in the rumen fluid and corrected to apply to rumen fluid outflow (see p. 398) apply to all the water flowing to the omasum. Nevertheless, the estimated protozoal contribution to microbial $\mathrm{N}$ flow from the stomach of animals with normal fauna with and without urea in the present experiment was similar to the values reported by Punia \& Leibholz (1984) and Punia et al. (1984b) which were estimated by the ${ }^{35} \mathrm{~S}$ and ${ }^{15} \mathrm{~N}$ techniques.

Apparent digestibility of $\mathrm{N}$ in the total tract was not affected by the presence of protozoa, a finding similar to that of Lindsay \& Hogan (1972). Males \& Purser (1970) and Takahashi \& Kametaka (1976) observed increases in $\mathrm{N}$ retention due to defaunation but Whitelaw et al. (1984) reported that differences in $\mathrm{N}$ retention due to protozoa were not significant. The significant increase in the retention of $\mathrm{N}$ with the urea supplement is in agreement with the known effects of urea as a supplement to straws and hays of low $\mathrm{N}$ content (e.g. Campling et al. 1962; Bird, 1974; Coleman \& Barth, 1977). 


\section{Effects on rumen fermentation}

The observation of lower concentrations of rumen fluid $\mathrm{NH}_{3}-\mathrm{N}$ in animals with reduced fauna is in general agreement with the literature (e.g. Abou Akkada \& El-Shazly, 1964; Eadie \& Gill, 1971; Goetsch et al. 1984). Increased rumen $\mathrm{NH}_{3}-\mathrm{N}$ in the presence of protozoa results from protozoal action on dietary and bacterial protein (Coleman, 1967) and possibly protozoal protein.

Defaunation of the rumen has been reported to increase the molar proportions of propionate in the rumen fluid and decrease those of butyrate (e.g. Males \& Purser, 1970; Whitelaw et al. 1984). Similar results were obtained in the present study. However, Bird \& Leng (1978) observed lower acetate and higher butyrate proportions in defaunated cattle given molasses and oaten straw which probably reflect the nature of dietary ingredients and the type of microflora sustained on these substrates.

\section{Rumen volume and marker retention time}

The lower volume of water in the rumen with reduced fauna in the present study is in agreement with the observations of Kayouli et al. (1984). Veira et al. (1983), however, did not find changes in rumen water in defaunated sheep and Faichney \& Griffiths (1978) and Orpin \& Letcher (1984) observed more water in the rumen in the absence of protozoa. Veira et al. (1983) and Goetsch et al. (1984) did not find changes in the dilution rates of fluid markers due to defaunation and the absence of a significant effect of fauna on the mean retention time of CrEDTA in the present work is in agreement with these observations. By contrast, Faichney \& Griffiths (1978) and Faichney (1986) observed increased mean retention times of solute markers and Orpin \& Letcher (1984) observed decreases in fluid flow rates in the absence of protozoa.

\section{Conclusion}

It may be concluded from the results presented here that the presence of normal fauna in the rumen of cattle fed on low-quality hay enhances the digestion of OM. This may be brought about by increased cellulolytic activity of bacteria in the presence of protozoa (Jouany \& Senaud, 1979) as well as by the cellulolytic activity of ciliate protozoa (Jouany $\&$ Senaud, 1979, 1982; Orpin, 1984; Coleman, 1985). Further experiments using a variety of diets would help to specify further the role of ciliate protozoa in ruminant nutrition and production.

This study was funded by the Australian Meat Research Committee. The authors thank Mr R. Butchers for assistance in the management of animals, Mrs Helen Miller for help in laboratory analysis and Dr M. E. O'Neill for statistical advice. B.S.P. is a research scholar from the National Dairy Research Institute, Karnal (Haryana) India, under the Commonwealth Scholarship and Fellowship Plan.

\section{REFERENCES}

Abou Akkada, A. R. \& El-Shazly, K. (1964). Applied Microbiology 12, 384-390.

Bauchart, D., Legay-Carmier, F., Dorean, M. \& Jouany, J. P. (1986). Reproduction, Nutrition et Développement 26, 309-310.

Becker, E. R. \& Everett, R. C. (1930). American Journal of Hygiene 11, 362-370.

Binnerts, W. T., Van't Klooster, A. Th. \& Frens, A. M. (1968). Veterinary Record 82, 470.

Bird, P. R. (1974). Australian Journal of Agricultural Research 25, 631-642.

Bird, S. H., Hill, M. K. \& Leng, R. A. (1979). British Journal of Nutrition 42, 81-87.

Bird, S. H. \& Leng, R. A. (1978). British Journal of Nutrition 40, 163-167.

Bird, S. H. \& Leng, R. A. (1984). British Journal of Nutrition 52, 607-611.

Borhami, B. E. A., El-Shazly, K., Abou Akkada, A. R. \& Ahmed, I. A. (1967). Journal of Dairy Science 50, $1654-1660$. 
Broad, T. E. \& Dawson, R. M. C. (1975). Biochemical Journal 146, 317-328.

Burggraaf, W. \& Leng, R. A. (1980). New Zealand Journal of Agricultural Research 23, 287-291.

Campling, R. C., Freer, M. \& Balch, C. C. (1962). British Journal of Nutrition 16, 115-124.

Chalmers, M. I., Davidson, J., Eadie, J. M. \& Gill, J. C. (1968). Proceedings of the Nutrition Society 27, 29 A.

Chaney, A. L. \& Marbach, E. P. (1962). Clinical Chemistry 8, 130-132.

Christiansen, W. C., Kawashima, R. \& Burroughs, W. (1965). Journal of Animal Science 24, 730-734.

Coleman, G. S. (1967). Journal of General Microbiology 47, 449-464.

Coleman, G. S. (1985). Journal of Agricultural Science, Cambridge 104, 349-360.

Coleman, S. W. \& Barth, K. M. (1977). Journal of Animal Science 45, 1180-1187.

Conrad, H. R., Hibbs, J. W., Pounden, W. D. \& Sutton, T. S. (1950). Journal of Dairy Science 33, $585-592$.

Eadie, J. M. (1962). Journal of General Microbiology 29, 563-578.

Eadie, J. M. \& Gill, J. C. (1971). British Journal of Nutrition 26, 155-167.

Eadie, J. M. \& Hobson, P. N. (1962). Nature 193, 503-505.

Faichney, G. J. (1975). In Digestion and Metabolism in the Ruminant, pp. 277-291 [I. W. McDonald and

A. C. I. Warner, editors]. Armidale: University of New England Publishing Unit.

Faichney, G. J. (1980). Australian Journal of Agriculatural Research 31, 1129-1137.

Faichney, G. J. (1986). In Control of Digestion and Metabolism in Ruminants, pp. 173-195 [L. P. Milligan,

W. L. Grovum and A. Dobson, editors]. Englewood Cliffs, New Jersey: Prentice Hall.

Faichney, G. J. \& Griffiths, D. A. (1978). British Journal of Nutrition 40, 71-82.

Goering, H. K. \& Van Soest, P. J. (1970). Forage Fiber Analysis, Agricultural Handbook no. 37a, Washington, DC: Agricultural Research Service, United States Department of Agriculture.

Goetsch, A. L., Estell, R. E. \& Galyean, M. L. (1984). Proceedings, Western Section, American Society of Animal Science 35, 280-283.

Hibbs, J. W. \& Conrad, H. R. (1958). Journal of Dairy Science 41, 1230-1247.

Hungate, R. E. (1966). The Rumen and its Microbes. New York and London: Academic Press.

Jouany, J. P. \& Senaud, J. (1979). Annales De Recherches Vétérinaires 10, 261-263.

Jouany, J. P. \& Senaud, J. (1982). Reproduction, Nutrition et Développement 22, 735-752.

Jouany, J. P. \& Thivend, P. (1983). In 4th International Symposium on Protein Metabolism and Nutrition, vol. 2, Les Colloques de FINRA no. 16, pp. 287-290. Clermont-Ferrand, France: INRA.

Jouany, J. P., Zainab, B., Senaud, J., Groliere, C. A., Grain, J. \& Thivend, P. (1981). Reproduction Nutrition et Développement 21, 871-884.

Kayouli, C., Demeyer, D. I., Van Nevel, C. J. \& Denooven, R. (1984). Animal Feed Science and Technology 10, $165-172$.

Klopfenstein, T. J., Purser, D. B. \& Tyznik, W. J. (1966). Journal of Animal Science 25, 765-773.

Kurihara, Y., Eadie, J. M., Hobson, P. N. \& Mann, S. O. (1968). Journal of General Microbiology 51, $267-288$.

Kurihara, Y., Takechi, T. \& Shibata, F. (1978). Journal of Agricultural Science, Cambridge 90, 373-382.

Leng, R. A., Gill, M., Kempton, T. J., Rowe, J. B., Nolan, J. V., Stachiw, S. J. \& Preston, T. R. (1981). British Journal of Nutrition 46, 371-384.

Lindsay, J. R. \& Hogan, J. P. (1972). Australian Journal of Agricultural Research 23, 321-330.

Lovelock, L. K. A., Buchanan-Smith, J. G. \& Forsberg, C. W. (1982). Canadian Journal of Animal Science 62 , 299-303.

Males, J. R. \& Purser, D. B. (1970). Applied Microbiology 19, 485-490.

Mathers, J. C. \& Miller, E. L. (1980). British Journal of Nutrition 43, 503-514.

Moore, S. (1963). Journal of Biological Chemistry 238, 235-237.

Orpin, C. G. (1984). Animal Feed Science and Technology 10, 121-143.

Orpin, C. G. \& Letcher, A. J. (1984). Animal Feed Science and Technology 10, 145-153.

Pounden, W. D. \& Hibbs, J. W. (1950). Journal of Dairy Science 33, 639-644.

Punia, B. S. \& Leibholz, J. (1984). Canadian Journal of Animal Science 64, suppl., 24-25.

Punia, B. S., Leibholz, J. \& Faichney, G. J. (1984a). Proceedings of the Australian Society of Animal Production 15,733 .

Punia, B. S., Leibholz, J. \& Faichney, G. J. (1984b). Proceedings of the Australian Society of Animal Production $15,732$.

Smith, R. H. (1984). Proceedings of the Nutrition Society 43, 63-68.

Steel, R. G. D. \& Torrie, J. H. (1980). Principles and Procedures of Statistics, 2nd ed. New York: McGraw Hill.

Takahashi, F. \& Kametaka, M. (1976). Japanese Journal of Zootechnical Science 47, 192-196.

Ushida, K., Jouany, J. P., Lassalas, B. \& Thivend, P. (1984). Canadian Journal of Animal Science 64, Suppl., $20-21$.

Veira, D. M., Ivan, M. \& Jui, P. Y. (1983). Journal of Dairy Science 66, 1015-1022.

Veira, D. M., Ivan, M. \& Jui, P. Y. (1984). Canadian Journal of Animal Science 64, Suppl., 22-23.

Warner, A. C. I. (1962). Journal of General Microbiology 28, 129-146.

Whitelaw, F. G., Eadie, J. M., Bruce, L. A. \& Shand, W. G. (1984). British Journal of Nutrition 52, $261-275$.

Williams, P. P. \& Dinusson, W. E. (1973). Journal of Animal Science 36, 588-591. 